\title{
The Capacity of JESSICA Projects to Repay Loans Based on Own Revenues
}

\author{
Piotr Idczak, Ida Musiałkowska
}

\begin{abstract}
A B S T R A C T
Objective: Objectives of the article are the following: to identify 1) similarity/ dissimilarity in Polish regions with regard to the implementation of JESSICA projects in terms of the size of JESSICA loans/ projects and the legal form of beneficiaries, 2) what factors have the biggest impact on the project capacities to generate revenues.
\end{abstract}

Research Design \& Methods: The authors used the logistic regression to build a model showing the association of the variables analysed on the dependent variable. In addition, to point out a relative importance from all possible orderings of explanatory variables and to show the most important one(s), ANOVA method was applied.

Findings: Not all the projects co-financed under the JESSICA initiative bring revenues from their main operations. The legal form of a beneficiary plays an important role. Both projects implemented by companies and projects of a relatively high value increase the probability of generating revenues. Location of the project (capital city/ non-capital city of the region) is not significant with regard to capacities to generate revenues.

Implications \& Recommendations: JESSICA projects characterised with a high value and implemented by entities having the company status involve private capital and consequently generate capital backflows. They contribute to leverage effects and thereby raise the role of JESSICA as a powerful instrument aimed at rendering existing market failures. It seems that the results of the study might help to design the use of JESSICA resources in the current and the future EU financial perspective.

Contribution \& Value Added: The article sheds more light on a still under-researched area of the use of financial instruments in the EU Cohesion Policy. The analysis provides pioneering results and points out the vital issues for future research.

\begin{tabular}{|c|c|}
\hline Article type: & research article \\
\hline Keywords: & $\begin{array}{l}\text { JESSICA; Poland; regeneration; revenue-generating projects; Cohe- } \\
\text { sion Policy }\end{array}$ \\
\hline JEL codes: & R51, R53, R58, F36, H43 \\
\hline Received: 30 August 2018 & Accepted: 26 March 2019 \\
\hline
\end{tabular}

\section{Suggested citation:}

Idczak, P., \& Musiałkowska, I. (2019). The Capacity of JESSICA Projects to Repay the Loans Based on Own Revenues. Entrepreneurial Business and Economics Review, 7(2), 141-157. https://doi.org/10.15678/EBER.2019.070208 


\section{INTRODUCTION}

Urban areas, being in the focus of the study, require investment in urban infrastructure, heritage and cultural sites, deprived areas, housing, etc. Nevertheless, the financial resources of public and private entities have not been sufficient to respond to high demand in cities. Apart from grants and loans coming from the banking sector, there has been a new initiative introduced at the European level by the European Commission together with two public banks: the European Investment Bank and the Council of Europe Development Bank - the JESSICA (Joint European Support for Sustainable Investment in City Areas) initiative. The support offered under JESSICA is based on the use of the Cohesion Policy structural funds in a form of repayable financing. There are, however, still surprisingly few studies looking into a different nature of such financial aid (Bode, 2015; Dąbrowski, 2014, 2015; Fotino, 2014; Musiałkowska \& Idczak, 2016; Nadler \& Nadler, 2018). The majority of evaluation reports were done before or in the mid 2007-2013 financial perspective - for Śląskie and Pomorskie regions (CCI, 2010; EIB, 2010b) or Mazowieckie Region (EIB, 2011) and do not provide answers to in-depth research questions regarding e.g. the capacities of projects to ensure the repayability of JESSICA funding.

As reported by the authors in a previous study, one out of three projects implemented within the framework of JESSICA initiative does not generate any revenues (Musiałkowska \& Idczak, 2019). In addition, these preliminary findings suggest that the most desired projects from the JESSICA perspective are those of a high value and designed by private entities. These kinds of projects not only can provide revenues needed to fully cover the operating costs but also to ensure the repayment of the loan. To the authors' knowledge, there is no other empirical study to date that has considered JESSICA from the point of view of the project implementation. Therefore, the main objective of this study is to investigate the impact factors that may affect the capacities of the projects to generate revenues on the basis of their primary business activities. Special interest is in how variables such as the legal form of the beneficiary, project location, project value, value of the JESSICA loan, the region implementing the JESSICA initiative, the bank providing JESSICA loan influence the project capacities to generate own revenues, if any.

We concentrate on this intuitively obvious issue, taking into account the fact that the basic tasks of the JESSICA initiative are to develop an effective process for supporting urban development by revolving funds and to enhance and accelerate a potential for new investments in urban areas. According to the preliminary rules, only projects that generate return flows are eligible for funding offered by this instrument and the repayment should be achieved either in the form of solely commercial returns or project revenues secured directly by investors from other sources (Musiałkowska \& Idczak, 2018a). In our previous study we found out that not all projects bring revenues from the commercial returns and that the form of a beneficiary (public or private) matters. Thus, in order to achieve the objective set out, this study seeks to address the following specific issues: Which of the variables analysed significantly contributes to achieving capacities to generate own revenues by JESSICA projects? Which of the variables considered has the greatest impact on 
the project capacity to generate own revenues? Are there any differences between regions with regard to the number of projects that have received revenues from primary business activities? How does the project capacity to generate own revenues vary spatially in particular regions? Which projects meet the JESSICA requirements to the greatest possible extent? By providing answers to these questions, the study can shed further light in the debate on the implementation of revolving instruments in the regional and urban policy. Moreover, our study provides further evidence for the functioning of the JESSICA initiative and thereby bridges a gap in the literature on it.

The article is structured as follows. Section two describes briefly the JESSICA initiative in Poland. Section three provides details on data and methodology and is followed by section four that outlines the results and discusses the factors mostly influencing a project capacity to generate own revenues. The final section concludes with a brief discussion on the implications of the findings for the policy practice.

\section{LITERATURE REVIEW}

This new and innovative initiative - JESSICA - was created in order to increase the amount of money for investments related to sustainable development and regeneration processes in cities in the 2007-2013 financial perspective. The initiative that is implemented in the framework of the Cohesion Policy uses the resources of one of the structural funds - the European Regional Development Fund - in the form of revolving instruments (loans, guarantees), allowing for e.g. achieving the multiplier effect of the actions implemented (Memorandum of Understanding, 2006). JESSICA was developed by the European Commission in cooperation with the European Investment Bank (EIB) which can act as a trust fund manager and which works in cooperation with the Council of Europe Development Bank (CEB). In the years 2007-2013, this initiative was applied in 11 EU countries, including Poland (European Commission, 2014). In all five Polish regions: Mazowieckie, Pomorskie, Śląskie, Wielkopolskie, and Zachodniopomorskie that decided to implement JESSICA, the EIB was a beneficiary of the measures of regional operational programmes and performed a function of the so-called holding fund that cooperated with the specialised Urban Development Funds (that is: Bank Gospodarstwa Krajowego - BGK, Bank Ochrony Środowiska - BOŚ and Bank Zachodni WBK S.A. BZWBK S.A.), namely entities responsible for the selection of projects and providing cofinancing to them (Musiałkowska \& Idczak, 2018a).

JESSICA involved repayable funding which, contrary to grant-based assistance commonly available within the framework of $\mathrm{CP}$, was intended to provide in general private investors with incentives to encourage them to develop projects aimed at redressing imbalances in urban areas (Nadler \& Kreuz, 2011). The main strength of such a kind of funding was to trigger the catalytic effect of private as well as public capital available on the market, and thereby leverage other resources, in addition to EU Structural Funds, for urban renewal. The basic rule relies here on reinvesting both revenues generated by the investments and the reimbursement of principal amount in other urban projects (EIB, 2010a, pp. 45-48). This, in turn, means that only projects generating return flows, that is repayable investments, in principle can be financed from JESSICA funds (Mazars, 2013 , pp. 10-11). Since the generation of capital backflows is mandatory, projects should show an adequate level of financial profitability. In other words, they should ensure, in 
a dynamic capital budgeting analysis, cash inflows raising from sale revenues (i.e. flows directly paid by users for the goods or services provided by particular projects) that allow for retaining the profitability within the meaning of the financial internal rate of return (Arup, 2009, pp. 44-46; Nadler \& Nadler, 2018). In this context, projects should be characterised by a long-term viability and demonstrate a high self-financing level. Moreover, JESSICA was deemed to be a powerful catalyst for mobilising additional financial resources to encourage public-private partnership (PPP) solutions focused on the implementation of urban development projects (Held \& Jakubowski, 2009).

JESSICA, in general, supports projects in the following areas: urban infrastructure (including for transport, water and sewage systems or power), heritage or places relevant to culture (contributing to the development of tourism or another permanent use), development of brownfield sites (including cleaning and decontamination of the areas), creation of new commercial premises for small and medium-sized enterprises, development of information technology and research and development works, expansion of university buildings and improving energy efficiency (European Commission, 2013a). Almost all types of legal persons enumerated in the Polish law were eligible to apply for funds (for more see sections 3-4).

According to the European authorities involved in the design of the Cohesion Policy, this initiative should bring a number of benefits, of which the most important are the following (European Commission, 2013b):

- generating profits through projects implemented using financial engineering instruments,

- occurrence of leverage - by combining structural funds with other existing sources of funding,

- the initiative is to provide flexibility in structural terms regarding the usage of funds (in the form of equity, debt or guaranteed investments, which can be adapted to the specific needs of countries and regions),

- gaining know-how from private investors, which aims to facilitate the acquisition of further investments in the coming years and provide technical and financial performance in the implementation phase of the project and during its management,

- an increase in establishing partnerships between stakeholders such as: countries, regions, cities, EIB, CEB, other banks, investors, in order to solve problems of urban areas,

- emphasis put on the so-called social aspect of the projects, estimated based on the advantage of positive externalities of an urban project (the so-called social elements) over the commercial part of an investment,

- bigger complexity and diversity of the projects when comparing to the grant system (e.g. shopping malls, business incubators, office space, dormitories, hotels, underground parking, etc.).

The values of the available funds under JESSICA differed among the regions. Wielkopolskie region allocated the biggest amount of $66.3 \mathrm{mln}$ EUR, while Zachodniopomorskie region allocated the lowest amount that accounted for half of Wielkopolskie region allocation, namely $30 \mathrm{mln}$ EUR (Musiałkowska \& Idczak, 2018a). The projects of the highest values (and the highest value of the JESICA loan) were implemented in Zachodniopomorskie region, whereas the biggest differentiation in terms of the project values was observed in Pomorskie region (Figure 1). 


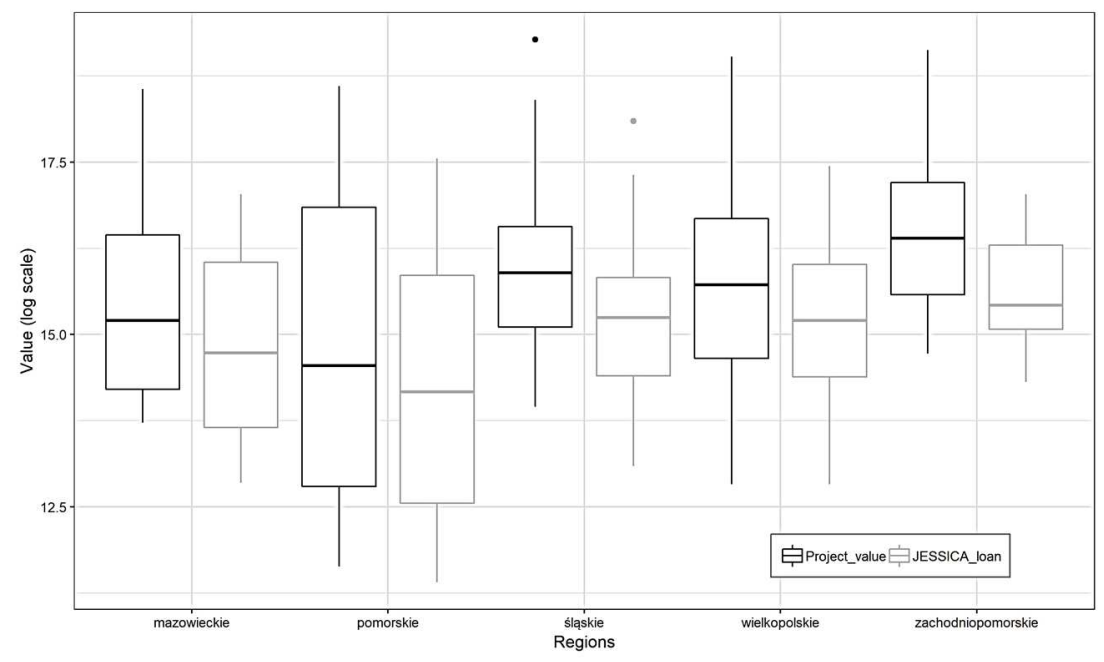

Figure 1. The value of JESSICA projects and loans in Polish regions (log scale) Source: own elaboration.

\section{MATERIAL AND METHODS}

The empirical analysis in this study covers all projects implemented within the framework of the JESSICA initiative in Poland during the 2007-2015 period ${ }^{1}$. The investigation presented here draws on data collected from the following sources: the Marshall Offices of all regions implementing the JESSICA initiative and institutions acting as managers of the Urban Development Funds. In addition, this database was completed with information about the legal form of beneficiaries from the National Court Register. The other data regarding projects was supplemented by the results of examination of other sources, such as project descriptions, policy reports, and field studies. Secondary sources, in particular multiple online resources, were also used to find missing information.

In order to meet the goals identified above in the introduction, we undertook a fourpronged approach. First, we identified how many projects have received revenues from primary business activities, and which of them have gained revenues derived outside their main operations. We wanted to expound whether the capacities of JESSICA projects to generate own revenues vary in certain attributes and factors that may affect the performance of the JESSICA initiative. First of all, we aimed to examine if there is any statistical dependency between the project capacity to generate own revenues and the amount of JESSICA funding or the value of JESSICA projects. Furthermore, we considered the legal form of the beneficiary as an important factor that may also have an impact on the project capacity to generate own revenues. Generally, the beneficiaries represent 20 different types of legal forms. Therefore, for the purpose of statistical calculations, we grouped them first into two main categories: 1) public entities - acting in the widely defined social

\footnotetext{
${ }^{1} \mathrm{~N}+2$ rule was taken into account when considering the implementation of the projects.
} 
and public interest and 2) private entities - operating for profit. In the next step, we extracted within each category those types of beneficiaries that largely outnumbered the other types. We decided to investigate as a separate legal form those of the entities that have a company status. The same procedure was used to take a local government authority as a separate legal form as well. The rationale behind this is the fact that they represent legal forms of the two largest groups of beneficiaries. Another factor taken into consideration in the study was location. Due to a relatively small number of projects in our study population (161), location was analysed in dichotomous terms, that is, whether the projects were implemented in the capital cities of the regions or in areas situated outside the capital cities. Additionally, the analysis also covered two other factors, namely region and urban development fund. By doing so, we wanted to find out whether these factors could influence the capacities of the projects to generate own revenues.

Second, we examined the dependence existing between all of the variables included in the study. Since the assessment of the statistical significance relies here upon comparing different groups of measures (numerical and categorical data), we applied the Wilcoxon rank sum test with continuity correction. It is a non-parametric test and can be used to compare two independent groups of the sample ${ }^{2}$.

In order to explain whether the JESSICA projects are characterised by the capacity to generate revenues from their primary business activities, we used a logistic regression that allows us to estimate the probability of a binary response variable $(\mathrm{Y})$ based on predictor variables (X) (Lever, Krzywinski, \& Altman, 2016). The model in the simple form is the following:

$$
\log \left(\frac{p(X)}{1-p(X)}\right)=\beta_{0}+\beta_{1} X_{1}+\beta_{2} X_{2}+\cdots+\beta_{X} X_{X}
$$

where the odds ratio is defined by the function of the probability of success, that is, of having capacity to generate revenues $(Y=1)$ which is given by the fact that a particular project is a revenue-generating project, and the probability of failure otherwise. $\beta_{0}$ is the fixed component and is an integral part of the model, while $\left(\beta_{1}, \beta_{2}, \ldots, \beta_{p}\right)$ are regression coefficients associated with particular independent variables and must be estimated with the use of the maximum likelihood. $\left(X_{1}, X_{2}, \ldots, X_{p}\right)$ stand for $p$ predictors and are respectively: type of the beneficiary; company status; local government authority status (LGA), etc.

Finally, because we used multiple predictor variables in the regression model we also wanted to find out which variable is the most influential in predicting the binary response (Y) variable. This was done by applying ANOVA analysis that assesses potential differences in a ratio-scale dependent variable by categorical independent variables. All calculations were done in the R statistical package (R Core Team, 2018).

\section{RESULTS AND DISCUSSION}

As mentioned before, JESSICA projects should have a long-term viability and demonstrate a high self-financing level. However, as Table 1 shows, nearly one in every three projects

\footnotetext{
${ }^{2}$ It is assumed that it tests with the null hypothesis that the distribution of given measurements in population $\mathrm{X}$ is the same as that in $\mathrm{Y}$ - to put this more precisely, the median difference between the first and the second measurement groups amounts to zero. If the medians of two populations differ, it points to a difference in the shapes of two distributions.
} 
implemented under the JESSICA initiative in Poland does not provide any financial profitability but also no revenues. Against this background, Zachodniopomorskie region stands out notably as a region where all projects feature the capacities to generate revenues on the basis of their primary business activities. In turn, at the bottom of the ranking is Pomorskie region in which more than a half of projects $(53.33 \%)$ do not demonstrate any revenues. In all remaining regions, this relationship remains at the level that is close to the general average. What is surprising is the fact that the framework of the JESSICA initiative did not provide for a desired scale of long-term viability. It is worth noting that, indeed, in many projects $(32.2 \%$, Table 1 ) the repayment of the loan was not been made from sale revenues but was secured by investors from other sources. Taking into account the assumption related to the meaning of category 'revenue-generating projects' (see footnote 2 ), it is likely to be that the number of the non-profit projects is even higher.

Table 1. Number of the JESSICA projects implemented in 2007-2015 according to the capacity to generate revenues

\begin{tabular}{|l|c|c|c|c|c|c|}
\hline \multicolumn{1}{|c|}{ Type of project } & $\begin{array}{c}\text { Mazowieckie } \\
\text { region }\end{array}$ & $\begin{array}{c}\text { Pomorskie } \\
\text { region }\end{array}$ & $\begin{array}{c}\text { Śląskie } \\
\text { region }\end{array}$ & $\begin{array}{c}\text { Wielkopol- } \\
\text { skie region }\end{array}$ & $\begin{array}{c}\text { Zachodnio-po- } \\
\text { morskie region }\end{array}$ & Total \\
\hline $\begin{array}{l}\text { Revenue-generating } \\
\text { projects (RGP) } \\
\text { (percentage) }\end{array}$ & 23 & 21 & 20 & 26 & 19 & 109 \\
\hline $\begin{array}{l}\text { Non-revenue-gener- } \\
\text { ating projects } \\
\text { (percentage) }\end{array}$ & 8 & 24 & 6 & 14 & $(100.00)$ & $(67.70)$ \\
\hline $\mathbf{N}$ & $(25.81)$ & $(53.33)$ & $(23.08)$ & $(35.00)$ & $(0.00)$ & 52 \\
$(31$ & $\mathbf{4 5}$ & $\mathbf{2 6}$ & $\mathbf{4 0}$ & $\mathbf{1 9}$ & $\mathbf{1 6 1}$ \\
\hline
\end{tabular}

Source: (Musiałkowska \& Idczak, 2018a).

In order to provide an additional explanation in the research, further analysis is focused on factors that may have an impact on the capacities of projects to generate revenues based on own resources. By doing so, we can point to these factors as well as these projects which best reflect the assumption of JESSICA. Table 2 presents the most relevant categories of beneficiaries of JESSICA funding in terms of their legal status and other factors relevant for the study. As illustrated in Table 2, nearly half out of 57 beneficiaries clustered as public entities had to arrange other revenues than those stemming from charges paid by the users. Interestingly, a clearly distinguishable situation from other regions can be seen in Pomorskie region where a relatively high number of projects implemented by private entities was reported (32 out of 45 ) of which more than every second, on average, is able to generate revenues. When comparing these data, one may find this as a highly puzzling issue in particular because of the large number of 'private' projects (14 out of 32) that did not report any sale revenue from the core business. A similar situation occurs also in other regions (except for Zachodniopomorskie region) but the share of nonrevenue generating projects run by private entities is incomparably slight. The reason for this rather unexpected results can be accounted for by the fact that this type of beneficiaries also covers as project promotors housing cooperatives and housing communities. They implemented projects on 'energy efficiency improvements' which consisted, among others, in the modernisation of boiler plants, replacement of heating networks and im- 
provement of the thermal insulation of buildings, and also, for instance, in the modernisation of car parks and other infrastructural elements of a residential estate area. Those projects have undoubtedly made substantial contributions to achieving the savings in heat and energy consumption, and thus improving the environment and achieving the objective of social cohesion in a wider perspective. Nonetheless, this kind of projects does not provide sales revenues and thereby does not ensure any operational margin, and therefore the projects are financially unsustainable.

If one looks at the data relating to the location of JESSICA projects, the results show that at the general level a substantially larger number of projects was implemented in areas situated outside the capital cities of the regions (respectively compared 90 to 71). In this regard, the revenue-generating projects in both areas have a similarly high share. However, the situation varies within particular regions. For instance, Mazowieckie region almost doubled the number of projects implemented in other cities than the capital one, and in Wielkopolskie region more than three-fourths of projects were executed outside the capital city of the region. Hence, this is in contrast with what happened in Pomorskie region where two out of three projects were run within the Tricity. The figures concerning the capacity of project to generate own revenues in this context present a mixed picture. The same can be concluded as far as the Urban Developments Funds are concerned, where the data representing the share of the revenue-generating projects show a diverse picture as well. It should be noted, however, that the only outlier from the entirety of the figures seems to be Zachodniopomorskie region that is markedly different from other regions, in a positive sense of the line of the argument of this study.

The main goal of the subsequent analysis is to identify what factor contributed mostly to achieving the main assumptions of the JESSICA initiative. As stated in the Introduction, the research was carried out in order to examine the capacities of projects to generate revenues obtained from primary business activities of investors. To be more precise, we want to find out whether the capacities of projects to generate own revenues vary, for instance, in the amount of JESSICA funding or in the value of JESSICA projects. Moreover, we intend to reveal if there are other important factors such as legal form of beneficiaries, project location, UDF etc., that may affect the project capacities to generate own revenues and thereby could reflect an effect on the performance of the JESSICA initiative. For this reason the article now turns to investigate the relationship between the project capacities to generate own revenues and other variables to find the statistical dependences. To do so, we used the Wilcoxon rank sum test.

The results of the Wilcoxon rank sum test are displayed in Table 3. What clearly emerges from this table is the existence of the significant differences between the examined groups of variables. We can conclude that the variable 'project capacities to generate revenues' is significantly different when it comes to almost all variables, except for 'location' where the results show that the medians of both variables are almost equal with $W=2839.5$ and $p$-value $=0.9832$. Furthermore, results also highlight arelatively strong dependence between the variable $Y$ and the value of the JESSICA project, which was confirmed by the output of calculations: $W=765, p$-value $=7.555 e-14$. The same procedure was conducted regarding the statistical link between, on the one hand, the type of the beneficiary and the location, and on the other, the values of a JESSICA project 
and the value of JESSICA loan. We found that there are no significant differences between the location and the value of a JESSICA project as well as the JESSICA loan. This can be seen from the level of $p$-value, respectively 0.9959 and 0.8755 , which is higher than the significance level. For what concerns the relationship between the type of the beneficiary and both values, the test showed insufficient evidence with a $p$-value = 0.06604 in order to state that the distribution of the variable of the values of the JESSICA project differs significantly from that of the variable of the type of the beneficiary - it is rather weak. In brief, the most marked observation to emerge from the data analysis conducted so far is that the location, admittedly understood in dichotomous terms, seems not to be a relevant factor in the assessment of the JESSICA initiative.

Table 2. The number of JESSICA projects by legal form of the beneficiaries, location and UDF

\begin{tabular}{|c|c|c|c|c|c|c|}
\hline Term & $\begin{array}{l}\text { Mazowie- } \\
\text { ckie region }\end{array}$ & $\begin{array}{c}\text { Pomorskie } \\
\text { region }\end{array}$ & $\begin{array}{l}\text { Śląskie } \\
\text { region }\end{array}$ & $\begin{array}{l}\text { Wielkopol- } \\
\text { skie region }\end{array}$ & $\begin{array}{l}\text { Zachodnio-po- } \\
\text { morskie region }\end{array}$ & Total \\
\hline Public entities & $11(6)$ & $13(7)$ & $15(8)$ & $20(7)$ & $2(2)$ & $57(30)$ \\
\hline $\begin{array}{l}\text { - including local govern- } \\
\text { ment authorities }\end{array}$ & $5(3)$ & $8(5)$ & $7(6)$ & $18(6)$ & $2(2)$ & $40(22)$ \\
\hline Private entities & $20(17)$ & $32(14)$ & $15(12)$ & $20(19)$ & $17(17)$ & $\begin{array}{l}104 \\
(79)\end{array}$ \\
\hline - including Companies & $18(17)$ & $15(14)$ & $12(11)$ & $19(18)$ & $16(16)$ & $80(76)$ \\
\hline $\begin{array}{l}\text { Location in the capital city } \\
\text { of the region }\end{array}$ & $11(5)$ & $31(14)$ & $12(12)$ & $9(9)$ & $8(8)$ & $71(48)$ \\
\hline $\begin{array}{l}\text { Location outside the capi- } \\
\text { tal city of the region }\end{array}$ & $20(18)$ & $14(7)$ & $14(8)$ & $31(17)$ & $11(11)$ & $90(61)$ \\
\hline \multicolumn{7}{|l|}{ Urban Development Fund } \\
\hline - including: BGK & $31(23)$ & $32(14)$ & & $40(26)$ & & $\begin{array}{l}103 \\
(63)\end{array}$ \\
\hline BOŚ S.A. & & $13(7)$ & $26(20)$ & & $10(10)$ & 49 (37) \\
\hline BZ WBK & & & & & $9(9)$ & $9(9)$ \\
\hline Total (N) & 31 & 45 & 26 & 40 & 19 & 161 \\
\hline
\end{tabular}

Numbers of projects generating revenues are presented in parentheses.

Private entities include a broad category of actors registered according to the Polish law as companies, nongovernmental organisations, etc. We aggregated all beneficiaries into two main groups: public and private.

The term 'capital city' used in the table refers, as a rule, to capital city of the particular region, however with the exception of regions, i.e. Pomorskie region and Śląskie region, where, due to their specificity and agglomerative linkages, one continuous urban area covers more than the only one main city. Thus, in Pomorskie region the term 'capital city' comprises three cities: Gdańsk, Gdynia, Sopot, that is, the so called Tricity, and in Śląskie region it applies to the Upper Silesian conurbation including the cities: Chorzów, Dąbrowa Górnicza, Gliwice, Katowice, Ruda Śląska, Sosnowiec, Świętochłowice, Zabrze.

Source: own study.

A further interesting aspect of the analysis refers to the examination of the relationship between our dummy dependent variable and other variables that influence (explain) whether or not the JESSICA projects have the capacity to generate revenues on the basis of their primary business activities. The final set of explanatory variables $(X)$ used in the estimation includes the following: type of the beneficiary; company status; local government authority status (LGA); region; urban development fund (UDF) and value of the JESSICA project. The other variables considered, as for instance location and 
value of the JESSICA project were finally rejected due to their strong correlation with the others (for more see Figure 1 and Table 3).

Table 4 presents the coefficient estimates and other information that result from fitting our logistic regression model in order to predict the probability of having capacities to generate revenues by the projects. According to these results, it can be seen that only two variables suggest a statistically significant relationship in relation to our response variable, that is, Company status - YES and Value of the JESSICA project. When looking at the estimates, one can observe that the coefficients are positive and amount to $\beta$ company status $=$ 3.49289 and $\beta$ Value of the JESSICA project $=0.87224$. This indicates that an increase in both variables is associated with an increase in the probability of having capacities to generate revenues by the projects. The findings indicate that the odds ratio that a project has the capacity to generate revenues is 3.5 times higher for projects which were implemented by entities having the company status compared to other entities having different legal status. In turn, in the case of the second significant variable - value of the JESSICA project which is a continuous predictor, the estimate can be interpreted as - for every one unit (log scale) increase in the value of the JESSICA project the odds ratio of having capacities to generate revenues by the projects increases by $87 \%$. Thus, it can be generally concluded that the projects with the highest capacity for producing revenues on the basis of their primary business activities are those of high value and implemented by investors with the company status. One possible explanation for this is that large projects run by companies encompass a wide range of actions that are strictly geared to achieving the required profit. These kinds of investments target actions necessary to achieve the project objectives but also to generate return on investment, which covers both investment and operating costs, and makes a profit. It is also found that there is no significant relationship between regions, urban development funds and the project capacities to generate revenues.

Table 3. Identification of differences based on the Wilcoxon rank sum test

\begin{tabular}{|c|c|c|c|c|c|}
\hline $\begin{array}{l}\text { Comparison } \\
\text { of the two distributions }\end{array}$ & $w$ & p-value & $\begin{array}{l}\text { Comparison } \\
\text { of the two distributions }\end{array}$ & $w$ & $p$-value \\
\hline \multicolumn{3}{|c|}{ As ' $\mathrm{Y}$ ' project capacities to generate revenues } & \multicolumn{3}{|c|}{ As ' $Y$ ' type of the beneficiary } \\
\hline value of the JESSICA project & 765.0 & $7.555 \mathrm{e}-14$ & value of the JESSICA project & 3692 & 0.01012 \\
\hline value of the JESSICA loan & 981.0 & $2.128 \mathrm{e}-11$ & value of the JESSICA loan & 3484 & 0.06604 \\
\hline type of the beneficiary & 3798.0 & $3.588 \mathrm{e}-05$ & location & 3357 & $2.043 e-05$ \\
\hline location & 2839.5 & 0.9832 & As ' $\mathrm{Y}$ ' location & & \\
\hline companies & 1076.0 & $2.194 \mathrm{e}-13$ & value of the JESSICA project & 3193 & 0.9959 \\
\hline local government authorities & 3243.0 & 0.04849 & value of the JESSICA loan & 3241 & 0.8755 \\
\hline
\end{tabular}

Significance levels: statistically significant at the $p<0.05$ level.

Source: own study.

A closer look at the other predictors reveals that they became insignificant in explaining the probability of having capacities to generate revenues by the projects. The p-values associated with most of these variables are very high, indicating that there is no statistically significant association between these explanatory variables and our response variable. However, the positive value of the coefficient estimate for the type of the beneficiary - public, by the way of illustration, points out that public entities are more likely to implement projects generating revenues than the private ones. The same 
also refers to the LGA status - YES where an increase in LGA status is associated with an increase in the probability of generating revenues. These findings seem to contrast with an earlier study by (Musiałkowska \& Idczak, 2018a) highlighting that the capacity of projects to generate revenues is higher when they are implemented by private entities. There is a possible explanation for this outcome. Private entities tend to generate profits more frequently than public ones, which causes them to have higher probability of occurring capacities to generate revenues when the company status is not considered. However, if we exclude from the group 'private entities' those with the company status, it turns out that they have an overall higher probability of generating revenues than other forms. Thus, when using many predictors public entities may show a higher probability of generating revenues than private ones because the latter also cover a number of entities that do not generate profit (for instance, housing associations and communities). Given that these findings are based on an insignificant association between variables, the results from this part of the analysis should thus be treated with the utmost caution (for more see Wasserstein and Lazar, 2016). Generally, it can be stated that this study provides a more detailed insight into the matters of the factors affecting the probability of generating revenues. The effect display for all of the predictors included in the model to explain the project capacities to generate revenues can be seen in Figure 2 .

Table 4. Coefficients of logistic regression for the JESSICA projects implemented in Poland

\begin{tabular}{|c|c|c|c|c|c|c|}
\hline Term & Estimate & Std.error & Statistic & p.value & Devianc & e Residuals \\
\hline Intercept & -14.04977 & 3.64180 & -3.858 & $0.000114 * * *$ & Min & -2.2990 \\
\hline $\begin{array}{l}\text { Type of the beneficiary - } \\
\text { public }\end{array}$ & 0.93195 & 0.99125 & 0.940 & 0.347125 & 10 & -0.2367 \\
\hline Company status - YES & 3.49289 & 1.01945 & 3.426 & $0.000612 * * *$ & Median & 0.1455 \\
\hline LGA status - YES & 0.51902 & 0.69037 & 0.752 & 0.452173 & $3 Q$ & 0.4391 \\
\hline Region-Pomorskie & -0.67245 & 0.93601 & -0.718 & 0.472498 & Max & 1.7985 \\
\hline Region-Śląskie & -0.09454 & 1.31065 & -0.072 & 0.942498 & \multirow{6}{*}{$\begin{array}{c}\text { Pseudo- } \\
\mathrm{R}^{2}\end{array}$} & \multirow{6}{*}{0.6561281} \\
\hline Region - Wielkopolskie & -0.86111 & 0.72293 & -1.191 & 0.233596 & & \\
\hline \begin{tabular}{|l|} 
Region - \\
Zachodniopomorskie \\
\end{tabular} & 15.67709 & 1708.99057 & 0.009 & 0.992681 & & \\
\hline UDF - BOŚ S.A. & 0.25502 & 1.05065 & 0.240 & 0.808221 & & \\
\hline UDF - BZ WBK & 1.60222 & 2488.57915 & 0.001 & 0.999486 & & \\
\hline $\begin{array}{l}\text { Value of the JESSICA } \\
\text { project (log) }\end{array}$ & 0.87224 & 0.24886 & 3.505 & $0.000457 * * *$ & & \\
\hline
\end{tabular}

Significance levels: '.' statistically significant at the $p<0.10$ level; ${ }^{*}$ statistically significant at the $p<0.05$ level; ${ }^{* *}$ statistically significant at the $p<0.01$ level, $* * *$ statistically significant at the $p<0.001$ level. Null deviance: 202.57 on 160 degrees of freedom. Residual deviance: 100.45 on 150 degrees of freedom. Number of Fisher Scoring iterations: 17. The goodness of fit for the logistic regression model was assessed based on the Nagelkerke's R squared. Source: own study.

After fitting the logistic regression model to a set of data, it is also reasonable to verify how well the proposed model fits the observed data. We used the Nagelkerke pseudo- $\mathrm{R}^{2}$ to assess the goodness of fit for our model. The level of pseudo-R2 coefficient amounts to $65.61 \%$ which represents a very good fit. The same conclusion can be drawn with regard to the comparison of differences between the null deviance and our model deviance. As 
highlighted in notes under Table 4, the value of the residual deviance is twice lower than the null deviance which points to a very good fit as well.

The results of ANOVA are presented in Table 5. These results are consistent with those of the logistic regression, i.e. they indicate that the projects implemented by companies and possessing a high value are significantly associated with capacities to generate revenues. The last column of this table shows a relative importance (contribution percentages) from all possible orderings of the predictors. It can be seen that value of the JESSICA project being slightly ahead of company status are the most important factors influencing the project capacity to generate revenues.

Table 5. Results of ANOVA for the JESSICA projects implemented in Poland

\begin{tabular}{|l|r|r|l|r|}
\hline \multicolumn{1}{|c|}{ Term } & \multicolumn{1}{c|}{ Statistic } & df & \multicolumn{1}{c|}{ p.value } & \multicolumn{1}{c|}{ p } \\
\hline Type of the beneficiary & 0.937036711 & 1 & 0.333041 & 2.618790 \\
\hline Company status & 15.102779060 & 1 & $0.000102 * * *$ & 42.208605 \\
\hline LGA status & 0.570658147 & 1 & 0.449998 & 1.594851 \\
\hline Regions & 3.766258716 & 4 & 0.438562 & 10.525780 \\
\hline UDF & 0.058653823 & 2 & 0.971099 & 0.163923 \\
\hline Value of the JESSICA project $(\log )$ & 15.345893520 & 1 & $8.95 \mathrm{E}-05 * * *$ & 42.888051 \\
\hline
\end{tabular}

Significance levels: ${ }^{* *}$ statistically significant at the $\mathrm{p}<0.001$ level.

Source: own study.

In short, the empirical analyses undertaken here suggest that the most desirable projects from the JESSICA perspectives are those of the high total value and implemented by companies. These types of projects are characterised by relatively large capacities to generate revenues resulting from their primary business activities. Moreover, many of them, mostly done by private entities, demonstrate strong capabilities to achieve fair commercial return on investment. This means that those projects not only ensure the repayment of the JESSICA loan by their own but also were able to overcome market failures through introducing or restoring market activities in deprived urban areas.

\section{CONCLUSIONS}

This article provides empirical evidence of the JESSICA initiative in five Polish regions showing key information about its institutional frameworks and urban projects implemented with the use of the repayable funds. In particular, it investigates what factors influence the capacities of JESSICA projects to generate revenues on their own and identifies the factors that have the most significant impact on the viability of projects and their high self-financing level.

The general results of the analysis suggest that every third project executed mainly by public entities do not provide any revenues. Further, slightly more than a half of all beneficiaries classified as public entities run non-revenue generating projects. Promoters of these projects had to cover their own repayment needs from other sources than sales revenues which, in turn, reduces notably the repayable nature of JESSICA financing. In addition, it is surprising that one in four projects implemented by private entities is marked by the lack of operating revenues as well. Those projects consists in particular in modernisation or improvement of physical and technical characteristics of residential infrastructure, and their 
main 'net value added' is created basically as a result of the reduction of operational costs due to savings engendered by the rise of energy efficiency.

Interesting insights come from the analysis of factors affecting the capacities of JESSICA projects to generate revenues based on own resources. The empirical results can be summarised as follows. First, the strong statistically significant association between the company status and the capacity of projects to generate revenues points to that the capacity of projects to generate revenues is higher when they are implemented by companies. Second,

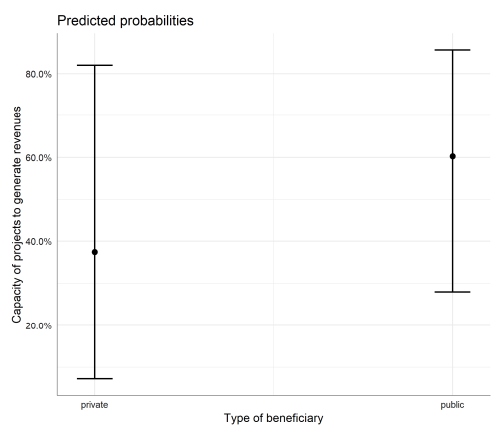

a) interaction effect of the type of beneficiary on the project capacity to generate revenues

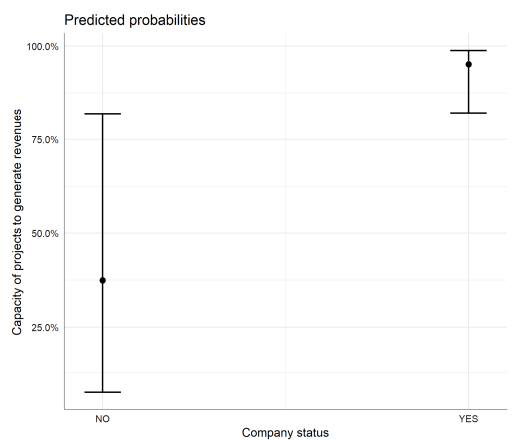

c) interaction effect of the company status on the project capacity to generate revenues

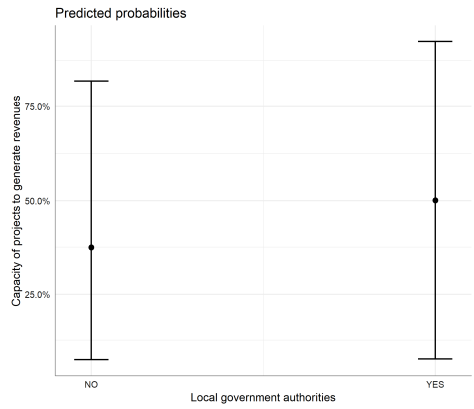

e) interaction effect of LGA on the project capacity to generate revenues

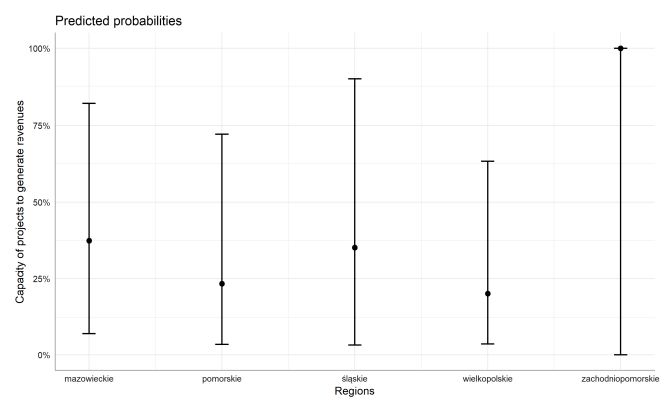

b) interaction effect of the regions on the project capacity to generate revenues

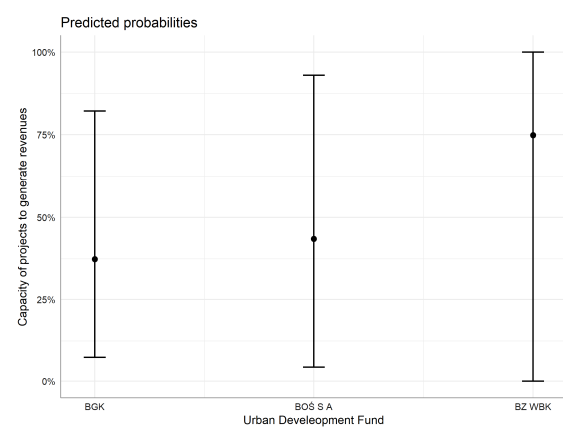

d) interaction effect of UDF on the project capacity to generate revenues

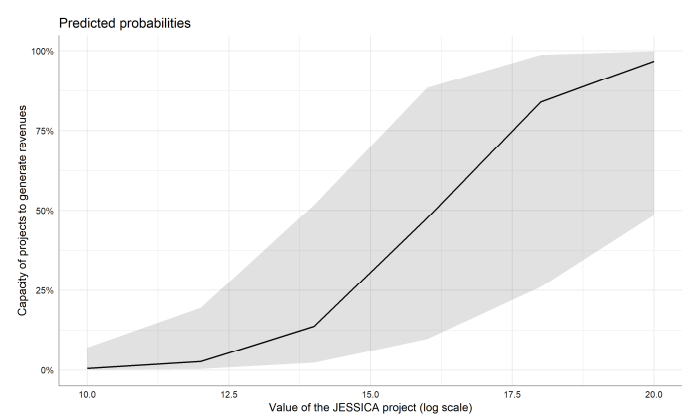

f) interaction plot of the value of the JESSICA project on the project capacity to generate revenues

Figure 2. Effect display for the predictors of the project capacity to generate revenues Source: own elaboration. 
the capacity of projects to generate revenues increases with the growing value of JESSICA projects. A parallel can be drawn here with the amount of the JESSICA loan which is due to strong correlations between both variables. Thus, findings emerging from the empirical analysis suggest that the most appropriate projects to be considered for JESSICA support are those of a high value and implemented by companies. Those kinds of projects covering often diversified business activities and offering a comprehensive range of services or goods are able not only to generate profits and ensure the repayment of the loan based on selffinancing capacity, but also they can provide, at the same time, positive externalities for the local citizens in line with the integrated urban development plans.

Another finding from the article confirms that, despite differentiation and dissimilarity of the approach of regions to the implementation of the projects in terms of the value of the JESSICA loan and their scope, location understood as capital city/ non-capital city relation is insignificant. Furthermore, it should also be stressed that only few authors have dealt with the importance of JESSICA for the transformation of urban areas, focusing at the same time mainly on qualitative research (see e.g. Dąbrowski, 2014, 2015; Fotino, 2014; Musiałkowska \& Idczak, 2018b; Tarnawska \& Rosiek, 2015) or examining its institutional framework (Bode, 2015; Nadler \& Nadler, 2018). Our study provides, for the first time, empirical evidence on all projects implemented in Poland with the use of JESSICA funds and on this basis those findings have a more profound effect on the knowledge of JESSICA initiative compared to previous results reported in the literature.

It can be concluded that a clear policy implication follows from the findings of our article. The projects characterised by a high value and proposed by entities having the company status involve private capital and consequently do generate capital backflows. In this sense, they contribute to the leverage effects and thereby raise the role of JESSICA as a powerful instrument aimed at rendering existing market failures. However, this analysis can become more sophisticated if leverage effects are measured. Indeed, more research is necessary to resolve this limitation of the study. Nevertheless, these results can be considered to be an important contribution to the debate on the potential solutions concerning the implementation of the JESSICA initiative in the current and next financial period.

\section{REFERENCES}

Arup. (2009). JESSICA Evaluation Study - West Poland. Retrieved from http://www.eib.org/ attachments/jessica-poland-west_en.pdf on December 1, 2018.

Bode, M. (2015). Financial Instruments in Cohesion Policy. European Structural and Investment Funds Journal, 3(3), 173-186.

CCI. (2010). JESSICA Evaluation Study for Silesia. Retrieved from https://www.eib.org/attachments/ documents/jessica-evaluation-study-for-silesia-en.pdf on November 1, 2018.

Dąbrowski, M. (2014). Engineering Multilevel Governance? Joint European Support for Sustainable Investment in City Areas (JESSICA) and the Involvement of Private and Financial Actors in Urban Development Policy. Regional Studies, 48(12), 2006-2019. https://doi.org/10.1080/00343404.2014.914625

Dąbrowski, M. (2015). 'Doing more with less' or 'doing less with less'? Assessing EU cohesion policy's financial instruments for urban development. Regional Studies, Regional Science, 2(1), 73-96. https://doi.org/10.1080/21681376.2014.999107

EIB. (2010a). JESSICA - Holding Fund Handbook. Luxembourg. Retrieved from http://www.eib.org/ 
attachments/documents/jessica_holding_fund_handbook_en.pdf on November 1, 2018.

EIB. (2010b). JESSICA Evaluation Study for Pomerania. Retrieved from https://ec.europa.eu/ regional_policy/archive/funds/2007/jjj/doc/pdf/jessica/poland_evaluation_pomerania.pdf on November 1, 2018.

EIB. (2011). JESSICA Evaluation Study. Implementing JESSICA Instruments in Mazowieckie Voivodship, Poland. Retrieved from https://ec.europa.eu/regional_policy/archive/ funds/2007/jjj/doc/pdf/ jessica/14-jessica_evaluation_study_in_mazowieckie_voivodship_en.pdf on November 5, 2018.

European Commission. (2013b). JESSICA: Joint European Support for Sustainable Investment in City Areas. Retrieved from https://ec.europa.eu/regional_policy/en/funding/special-support-instruments/ jessica/\#2 on November 5, 2018.

European Commission. (2013b). How does JESSICA work?. Retrieved from https://ec.europa.eu/ regional_policy/en/funding/special-support-instruments/jessica/\#3 on November 5, 2018.

European Commission. (2014). Summary of data on the progress made in financing and implementing financial engineering instruments reported by the managing authorities $n$ accordance with Article 67(2)(j) of Council Regulation (EC) No 1083/2006. Retrieved from https://ec.europa.eu/regional_policy/ sources/thefunds/instruments/doc/summary_data_fei_2013.pdf on November 1, 2018.

Fotino, F. (2014). The JESSICA Action in Italy 2007-2013. Bottlenecks, Opportunities, and Directions for the Future. European Structural and Investment Funds Journal, 2(3), 245-255. Retrieved from https://estif.lexxion.eu/article/ESTIF/2014/3/9 on November 1, 2018.

Held, T., \& Jakubowski, P. (2009). JESSICA und Stadtentwicklungsfonds - Neue Aufgaben für alte Landesentwicklungsgesellschaften?. Raumforschung Und Raumordnung, 67(1), 69-78. https://doi.org/10.1007/BF03183144

Lever, J., Krzywinski, M., \& Altman, N. (2016). Logistic regression. Nature Methods, 13(7), 541-542. https://doi.org/10.1038/nmeth.3904

Mazars. (2013). Financial Management in JESSICA Implementation Designing. Guarantee Products. Retrieved from http://www.eib.org/attachments/ documents/jessica_fg_final_ report_en.pdf on November 1, 2018.

Memorandum of Understanding. (2006). Memorandum of Understanding in Respect of a Coordinated Approach to the Financing of Urban renewal and Development for Programming Period 2007-2013 of the Community Structural Funds between the European Commission, the European Investment Bank and the Cou. Retrieved from http://ec.europa.eu/ regional_policy/archive/funds/2007/jjj/doc/pdf/urban_mou_signed.pdf on October 15, 2018.

Musiałkowska, I., \& Idczak, P. (2016). The use of repayable financial instruments in the process of regeneration of degraded urban areas on the example of the JESSICA initiative. In Changes and Challenges in the Modern World Economy (1st ed., Vol. 1, pp. 115-136). Poznań: PUEB Press. Retrieved from https://depot.ceon.pl/handle/123456789/12083 on November 1, 2018.

Musiałkowska, I., \& Idczak, P. (2018a). Is the JESSICA initiative truly repayable instrument? The Polish case study. Research Papers of Wrocław University of Economics, 536,143-151. https://doi.org/10.15611/pn.2018.536.13.

Musiałkowska, I., \& Idczak, P. (2018b). Ocena dopasowania projektów realizowanych w ramach inicjatywy JESSICA do potrzeb występujacych na obszarach miejskich. Studia KPZK PAN, 184, 233-246.

Nadler, M., \& Kreuz, C. (2011). UDF typologies and governance structures in the context of JESSICA implementation. Brussels. Retrieved from https://ec.europa.eu/regional_policy/archive/funds/ 2007/jjj/doc/pdf/jessica/udf_typologies.pdf on October 15, 2018.

Nadler, M., \& Nadler, C. (2018). Promoting investment in sustainable urban development with JESSICA: Outcomes of a new EU policy initiative. Urban Studies, 55(9), 1839-1858. 
https://doi.org/10.1177/0042098017702815

R Core Team. (2018). R: A language and environment for statistical computing. R Foundation for Statistical Computing. Retrieved from https://www.r-project.org/ on November 1, 2018.

Tarnawska, K., \& Rosiek, J. (2015). The Jessica Initiative: An Instrument for Urban Sustainable Development. Examples of Urban Regeneration in Silesia (Poland) and Central Moravia (Czech Republic) / Inicjatywa Jessica Jako Instrument Wspierania Zrównoważonego Rozwoju Miast. Przykłady Rewita. Comparative Economic Research, 18(2), 119-138. https://doi.org/10.1515/cer-2015-0015

Wasserstein, R.L., \& Lazar, N.A. (2016). The ASA's Statement on p-Values: Context, Process, and Purpose. The American Statistician, 70(2), 129-133. https://doi.org/10.1080/00031305.2016.1154108

\section{Authors}

The contribution of co-authors is diversified and can be expressed as 55\% Piotr Idczak and 45\% Ida Musiałkowska.

\section{Ida Musiałkowska}

Associate Professor at Department of European Studies, Poznań University of Economics and Business (Poznań, Poland). Her research interests are dynamics of regional integration and development processes in the EU and world, EU cohesion policy, European integration, Latin American integration, regional business cycles and policy transfer.

Correspondence to: Dr hab. Ida Musiałkowska, prof. UEP, Poznań University of Economics and Business, Department of European Studies, al. Niepodległości 10, 61-875 Poznań, Poland; +48 61 85433 09; e-mail: ida.musialkowska@ue.poznan.pl

ORCID (1) http://orcid.org/0000-0002-7054-7648

\section{Piotr Idczak}

Assistant Professor at Department of European Studies, Poznan University of Economics and Business (Poznań, Poland). His primary research interests encompass European integration, regional economic development with particular focus on the development of peripheral regions, urban regeneration, and the evaluation and analysis of financial engineering instruments used in the EU cohesion policy.

Correspondence to: Dr Piotr Idczak, Poznan University of Economics and Business, Department of European Studies, al. Niepodległości 10, 61-875 Poznań, Poland; + 486185433 06; e-mail: piotr.idczak@ue.poznan.pl

ORCID (1) http://orcid.org/0000-0002-3754-8956

\section{Acknowledgements and Financial Disclosure}

The study is supported by the National Science Centre, Poland (no. 2015/19/D/HS5/01561). Project 'Regeneration process of degraded urban areas within the framework of JESSICA initiative'.

The authors would like to acknowledge the statistical assistance of Maciej Beręsewicz, PhD. The authors would also like to thank the anonymous referees for their useful comments, which allowed to increase the value of this article.

This article has been presented as the academic paper at the scientific conference GLOB2018: "Globalization and Regionalization in the Contemporary World: Competitiveness, Development, Sustainability" organized in Kraków on 21-22 September 2019. 


\section{Copyright and License}

(9) (1) $\Theta$

This article is published under the terms of the Creative Commons

Attribution - NoDerivs (CC BY-ND 4.0) License

http://creativecommons.org/licenses/by-nd/4.0/

Published by the Centre for Strategic and International Entrepreneurship - Krakow, Poland

This publication has been co-financed by the European Commission Representation in Poland. The European Commission, or any person acting on its behalf, is not responsible for the use of the information contained in this publication. This publication Commission reflects the views only of the authors, and the European Commission cannot be held responsible for any use which may be made of the information contained therein. 
